University of Nebraska - Lincoln

DigitalCommons@University of Nebraska - Lincoln

Papers in the Earth and Atmospheric Sciences

Earth and Atmospheric Sciences, Department

8-2005

\title{
Cloud-to-Ground Lightning Production in Strongly Forced, Low- Instability Convective Lines Associated with Damaging Wind
}

\author{
Matthew S. Van Den Broeke \\ University of Nebraska-Lincoln, mvandenbroeke2@unl.edu \\ David M. Schultz \\ NOAA National Severe Storms Laboratory, david.schultz@noaa.gov \\ Robert H. Johns \\ Norman, OK \\ Jeffry S. Evans \\ NOAA/NWS/NCEP/Storm Prediction Center, Norman, Oklahoma \\ John E. Hales \\ NOAA/NWS/NCEP/Storm Prediction Center, Norman, Oklahoma
}

Follow this and additional works at: https://digitalcommons.unl.edu/geosciencefacpub

Part of the Earth Sciences Commons

\begin{abstract}
Van Den Broeke, Matthew S.; Schultz, David M.; Johns, Robert H.; Evans, Jeffry S.; and Hales, John E., "Cloud-to-Ground Lightning Production in Strongly Forced, Low-Instability Convective Lines Associated with Damaging Wind" (2005). Papers in the Earth and Atmospheric Sciences. 306.

https://digitalcommons.unl.edu/geosciencefacpub/306
\end{abstract}

This Article is brought to you for free and open access by the Earth and Atmospheric Sciences, Department of at DigitalCommons@University of Nebraska - Lincoln. It has been accepted for inclusion in Papers in the Earth and Atmospheric Sciences by an authorized administrator of DigitalCommons@University of Nebraska - Lincoln. 


\title{
Cloud-to-Ground Lightning Production in Strongly Forced, Low-Instability Convective Lines Associated with Damaging Wind
}

\author{
MatThew S. VAN DEN BROEKE \\ National Weather Center Research Experiences for Undergraduates, Norman, Oklahoma, and Valparaiso University, \\ Valparaiso, Indiana \\ DAVID M. SCHULTZ \\ Cooperative Institute for Mesoscale Meteorological Studies, University of Oklahoma, and NOAA/National Severe Storms Laboratory, \\ Norman, Oklahoma \\ ROBERT H. JOHNS \\ Norman, Oklahoma \\ JefFry S. Evans and John E. Hales \\ NOAA/NWS/NCEP/Storm Prediction Center, Norman, Oklahoma
}

(Manuscript received 20 September 2004, in final form 20 February 2005)

ABSTRACT

\begin{abstract}
During 9-11 November 1998 and 9-10 March 2002, two similar convective lines moved across the central and eastern United States. Both convective lines initiated over the southern plains along strong surfacebased cold fronts in moderately unstable environments. Both lines were initially associated with cloud-toground (CG) lightning, as detected by the National Lightning Detection Network, and both events met the criteria to be classified as derechos, producing swaths of widespread damaging wind. After moving into areas of marginal, if any, instability over the upper Midwest, CG lightning production ceased or nearly ceased, although the damaging winds continued. The 9 March 2002 line experienced a second phase of frequent CG lightning farther east over the mid-Atlantic states. Analysis of these two events shows that the production of CG lightning was sensitive to the occurrence and vertical distribution of instability. Periods with frequent CG lightning were associated with sufficient instability within the lower mixed-phase region of the cloud (i.e., the temperature range approximately between $-10^{\circ}$ and $-20^{\circ} \mathrm{C}$ ), a lifting condensation level warmer than $-10^{\circ} \mathrm{C}$, and an equilibrium level colder than $-20^{\circ} \mathrm{C}$. Periods with little or no CG lightning possessed limited, if any, instability in the lower mixed-phase region. The current Storm Prediction Center guidelines for forecasting these convective lines are presented.
\end{abstract}

\section{Introduction}

Mesoscale convective systems (MCSs) come in many shapes and sizes. Although numerous MCS classification schemes have been proposed in the past, forecasters at the National Weather Service/Storm Prediction Center (NWS/SPC) have noticed a type of MCS that occurs several times each year, but has not received much attention in the scientific literature. These narrow, quasi-linear MCSs are typically cool-season phenomena that occur along strong cold fronts where ap-

Corresponding author address: Dr. David M. Schultz, NOAA/ National Severe Storms Laboratory, 1313 Halley Circle, Norman, OK 73069.

E-mail: david.schultz@noaa.gov preciable low-level forcing for ascent is present. Swaths of widespread damaging wind reports are received, often meeting the criteria to be classified as derechos (e.g., Hinrichs 1888; Johns and Hirt 1987). Although cloud-to-ground (CG) lightning may be frequent at some stages during the MCS's lifetime, the defining characteristic of these MCSs is that a stage or stages occur where these MCSs produce little, if any, CG lightning, despite continuing to produce damaging winds. ${ }^{1}$

\footnotetext{
${ }^{1}$ Holitza and Kasemir (1974), Kasemir et al. (1976), Rust and Krehbiel (1977), and Maddow et al. (1997) provide examples of isolated thunderstorms where the production of CG lightning was significantly reduced when they were seeded with chaff, either deliberately or nondeliberately. The strongly forced, lowinstability convective lines in this study do not appear to be associated with chaff releases.
} 
As is shown later in this paper, these periods of little or no CG lightning are usually associated with limited instability; thus, the height of radar echoes or the tops of the convective clouds may be less than are typically associated with MCSs producing severe weather. The SPC has referred to these MCSs colloquially as "narrow, low-topped squall lines" or "F2 cold fronts," although we refer to them in this paper as strongly forced, low-instability convective lines.

This type of convective line poses a dilemma for NWS forecasters. Severe thunderstorm watches and warnings may not seem appropriate because CG lightning is usually absent (i.e., there may be no thunder occurring with the "thunderstorms") and the strong gradient winds associated with the synoptic-scale systems may approach severe criteria of $50-\mathrm{kt}\left(26 \mathrm{~m} \mathrm{~s}^{-1}\right)$ gusts outside of the convective line. Furthermore, synoptic-scale high-wind warnings may not seem appropriate either because the wind damage typically occurs on the mesoscale with the passage of the convective line. [High-wind warnings are defined by 1 -min-average surface winds over land of $35 \mathrm{kt}\left(18 \mathrm{~m} \mathrm{~s}^{-1}\right)$ or greater lasting for $1 \mathrm{~h}$ or longer, or winds gusting to $50 \mathrm{kt}$ (26 $\mathrm{m} \mathrm{s}^{-1}$ ) or greater regardless of duration.] In addition, no mechanism exists within the NWS to identify severe wind reports as convective, but nonthundering. This potential dilemma for NWS forecasters may be reflected by differences in reporting practice at local forecast offices, illustrated by discontinuities in storm reporting across county warning area boundaries, causing confusion for users of NWS forecasts and affecting the climatology of storm reports (e.g., Weiss et al. 2002; Doswell et al. 2005).

Compounding these problems, an additional issue is how to classify the damage reports. Consider an event where strong synoptic-scale winds blow all morning, then an afternoon convective line with winds meeting severe criteria moves through producing damage, similar to the two events described later in this paper. Were human observers present when the damage occurred, and did they know the exact time it occurred? Such information is helpful in assessing whether the damage was associated with the synoptic-scale winds or the convective line. Was the damage possibly enhanced because the period of sustained synoptic-scale winds weakened trees and structures, making them more susceptible to fail during the convective winds? In such a case, how should such wind damage be classified: nonconvective or convective?

Little has been published on these strongly forced, low-instability convective lines. McCann (1978) presented three cases of convective storms over Kansas and Missouri producing damaging winds with little or no thunder. All three events had radar echo tops 20-24 kft $(6.1-7.3 \mathrm{~km})$. Although all three events were associated with a deep surface low and strong $3-5-\mathrm{km}$ winds, only one of the events occurred as a convective line (the other two were isolated cells). He found that traditional stability indices (i.e., lifted index, Showalter index, total totals, and SWEAT index) provided little guidance for forecasting the severity of these events. Koch and Kocin (1991) presented a mesoscale analysis of an unforecast, strongly forced, low-instability convective line on 28 December 1988 over the eastern United States. They noted the radar echo tops were 7-8 $\mathrm{km}$, bearing remarkable similarity to the shallow convection along narrow cold-frontal rainbands over the ocean, as presented by Browning and Pardoe (1973) and reviewed by Browning (1990). Finally, in their climatology of derechos, Evans and Doswell (2001) showed that many of their cases were strongly forced (i.e., associated with a strong surface cyclone and a mobile midtropospheric short-wave trough) with minimal, if any, instability.

These quasi-linear MCSs appear to be closely related to those discussed by Kain and Fritsch (1998) and Bryan and Fritsch (2000). Specifically, strong mesoscale, nonbuoyancy-driven ascent caused by the lowlevel convergence at the cold front acts on a prefrontal sounding with little or no instability, producing moist absolutely unstable layers and organized deep moist convection, termed slab convection (Bryan and Fritsch 2000). The mechanism or mechanisms of the strong surface winds is not exactly known, but given such a strong cyclonic system, these strong winds could be related to the transport of high-momentum air down from aloft. The mechanism(s) responsible for this transport could be the mesoscale downdraft associated with the circulation in an MCS (e.g., Wakimoto 2001, 279-285), the descending branch of the frontal circulation (e.g., Dorian et al. 1988), the descent in evaporatively cooled downdrafts, or a combination of these mechanisms. In addition, dynamically forced horizontal pressure gradients may be responsible for the strong winds (e.g., Bernardet and Cotton 1998). In deep, moist convection initiated along a surface-based cold front, diagnosing the relative contributions of each potential mechanism using synoptic-scale data is difficult, if impossible. Thus, we will not address the cause of the damaging surface winds in this paper.

The purpose of this paper is to understand more about these strongly forced, low-instability convective lines to help forecasters recognize these types of MCSs and improve their forecasts. Specifically why is CG lightning absent while damaging winds are ongoing? An additional purpose is to illustrate the potential dif- 
ficulty this phenomenon may cause in the present operational warning environment. The ingredients for CG lightning are discussed in section 2. Two cases are examined in this paper: 9-11 November 1998 in section 3 and 9-10 March 2002 in section 4. Section 5 summarizes the results of this paper and presents current SPC guidelines for coordinating these events.

\section{Ingredients for CG lightning}

To produce electrical charging inside a cloud, a process that can lead to CG lightning production, MacGorman and Rust (1998, 218-220) state that "strong" updrafts associated with "vigorous convective growth" should occur in the lower part of the mixed-phase region of the cloud. This statement is supported by previous research (e.g., Workman and Reynolds 1949; Reynolds and Brook 1956; Michimoto 1991, 1993). The mixed-phase region of the cloud is the region where supercooled liquid water and ice coexist. Ice generally begins to nucleate at temperatures colder than $-5^{\circ}$ to $-10^{\circ} \mathrm{C}$, depending on the type of ice nuclei, and supercooled liquid water generally freezes by homogeneous nucleation at $-40^{\circ} \mathrm{C}$ (e.g., Rogers and Yau 1989, chapter 9). Thus, the mixed-phase region of the cloud is generally considered to be the approximate region of temperature between $-10^{\circ}$ and $-40^{\circ} \mathrm{C}$. Interactions between the supercooled liquid water and the ice to form graupel in the mixed-phase region are believed to be responsible for producing the electrical charging that leads to lightning discharges in thunderstorms. In the presence of ice within a cloud, supercooled liquid water is supersaturated with respect to the ice, and, consequently, the Bergeron-Findeisen process leads to evaporation of the supercooled liquid water as the ice grows by deposition. Because this process can be quite efficient, strong updrafts are required to supply supercooled liquid water to maintain the mixed-phase region of the cloud and to support the weight of the growing graupel. What constitutes a "strong" updraft cannot be rigorously defined, but at least $6-7 \mathrm{~m} \mathrm{~s}^{-1}$ is generally believed to be the lower limit (e.g., Michimoto 1991; Zipser 1994; Petersen et al. 1996). Parcel theory predicts that $w_{\max }=(2 \cdot \mathrm{CAPE})^{1 / 2}$, where $w_{\max }$ is the maximum vertical motion expected from the release of convective available potential energy (CAPE). Thus, only $18-25 \mathrm{~J} \mathrm{~kg}^{-1}$ of CAPE are needed to obtain such vertical motions ideally. Of course, limitations to parcel theory (e.g., Lucas et al. 1994; Emanuel 1994, 168-172; Doswell and Markowski 2004) such as mixing will affect these values of CAPE in practice, but this calculation provides an estimate of the rough order of magnitude. That such small values of CAPE may determine whether lightning production occurs is sober- ing in light of issues about the ability of the rawinsonde to measure such small values of CAPE, the representativeness of environmental soundings (e.g., Brooks et al. 1994), and the most appropriate way to measure instability (e.g., Doswell and Rasmussen 1994; Craven et al. 2002).

A physically based parameter for operational lightning prediction has been developed by the SPC, and the successful application of this parameter (Bright et al. 2005) provides support in formulating this study. Bright et al. (2005) used three criteria to determine the likelihood of CG lightning. First, the lifting condensation level (LCL) must be warmer than $-10^{\circ} \mathrm{C}$, ensuring a low-level source of supercooled cloud water into the convective line. Second, the equilibrium level (EL) must be colder than $-20^{\circ} \mathrm{C}$, ensuring ice nucleation. Third, CAPE must be greater than 100-200 J kg-1 in the $0^{\circ}$ to $-20^{\circ} \mathrm{C}$ layer, in order to provide the necessary ascent for electrification. We agree with the first two criteria, but feel that adequate CAPE should be present in the approximate layer $-10^{\circ}$ to $-20^{\circ} \mathrm{C}$. Although we choose a different threshold than Bright et al. (2005), little theoretical or empirical evidence suggests which approach is superior. Further analysis of this problem would be welcome. Consequently, our working hypothesis is that the potential for CG lightning to occur increases as the amount of CAPE in the lower mixedphase region of the cloud (approximately $-10^{\circ}$ to $-20^{\circ} \mathrm{C}$ ) increases, given the $\mathrm{LCL}$ is warmer than $-10^{\circ} \mathrm{C}$ and the EL is colder than $-20^{\circ} \mathrm{C}$.

In this paper, observed soundings characteristic of the preline environment are examined to see if the above conditions are met. The $-10^{\circ}$ and $-20^{\circ} \mathrm{C}$ isotherms are located on observed soundings, and the vertical distribution of CAPE is assessed to infer the potential for strong updrafts in the lower mixed-phase region of the convective line. The National Lightning Detection Network (NLDN; Cummins et al. 1998) was used to assess the occurrence of CG lightning. Although intracloud lightning could have been occurring in the absence of CG lightning during these events, detecting it with the operational resources at the time of these case studies was not possible.

\section{The convective line of 9-11 November 1998}

At 0000 UTC 10 November 1998, a large-amplitude $500-\mathrm{mb}$ trough was moving out of the western United States, with strong diffluence over much of the central United States (Fig. 1a). This trough was associated with a 993-mb surface cyclone over central Kansas (Fig. 1b). Deep moist convection organized in a narrow line along the synoptic-scale cold front in Kansas and Oklahoma (Fig. 2a). Twelve hours later, the trough became nega- 


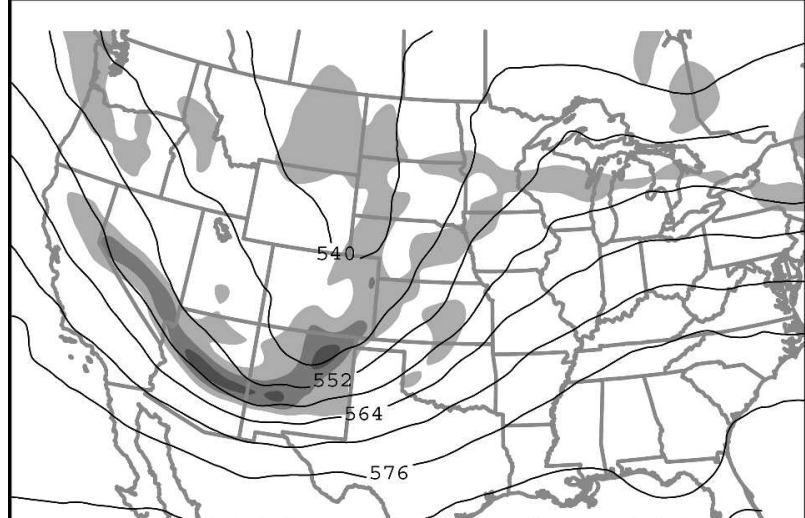

(a) 0000 UTC 10 NOV 1998 $\begin{array}{llll}15 & 25 & 35 & 45\end{array}$

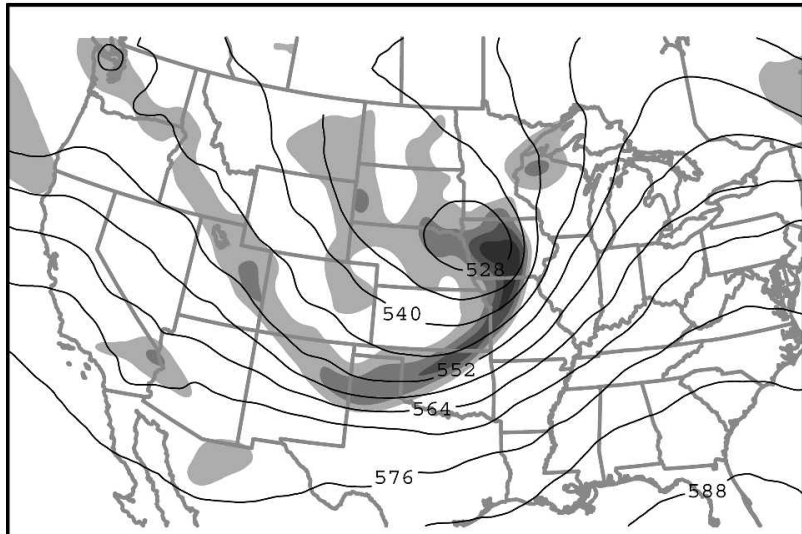

(c) 1200 UTC 10 NOV 1998

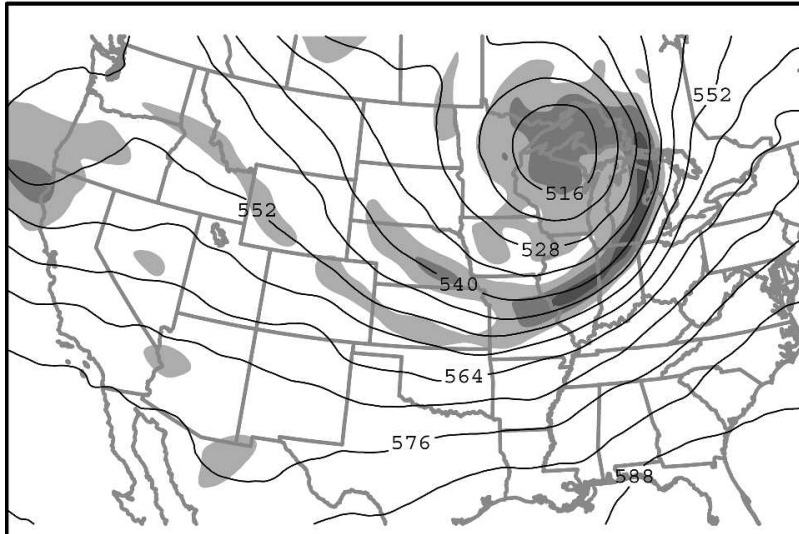

(e) 0000 UTC 11 NOV 1998

500-mb Geopotential Height and Absolute Vorticity

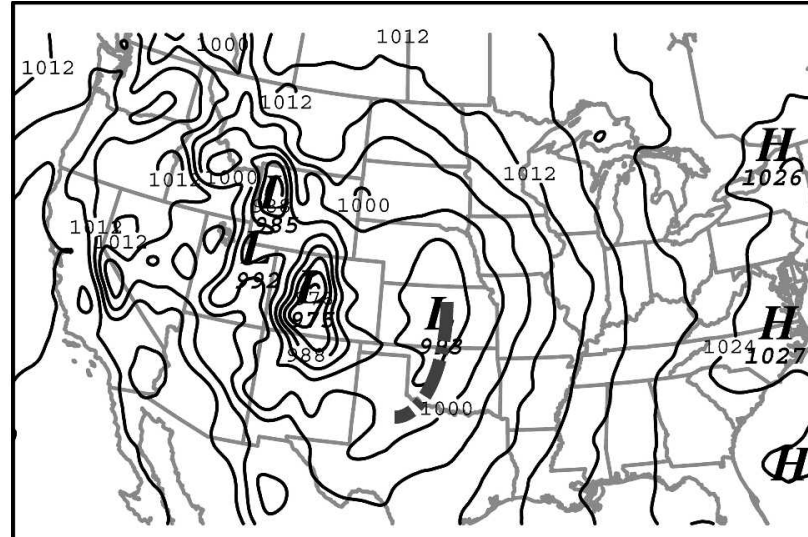

(b) 0000 UTC 10 NOV 1998
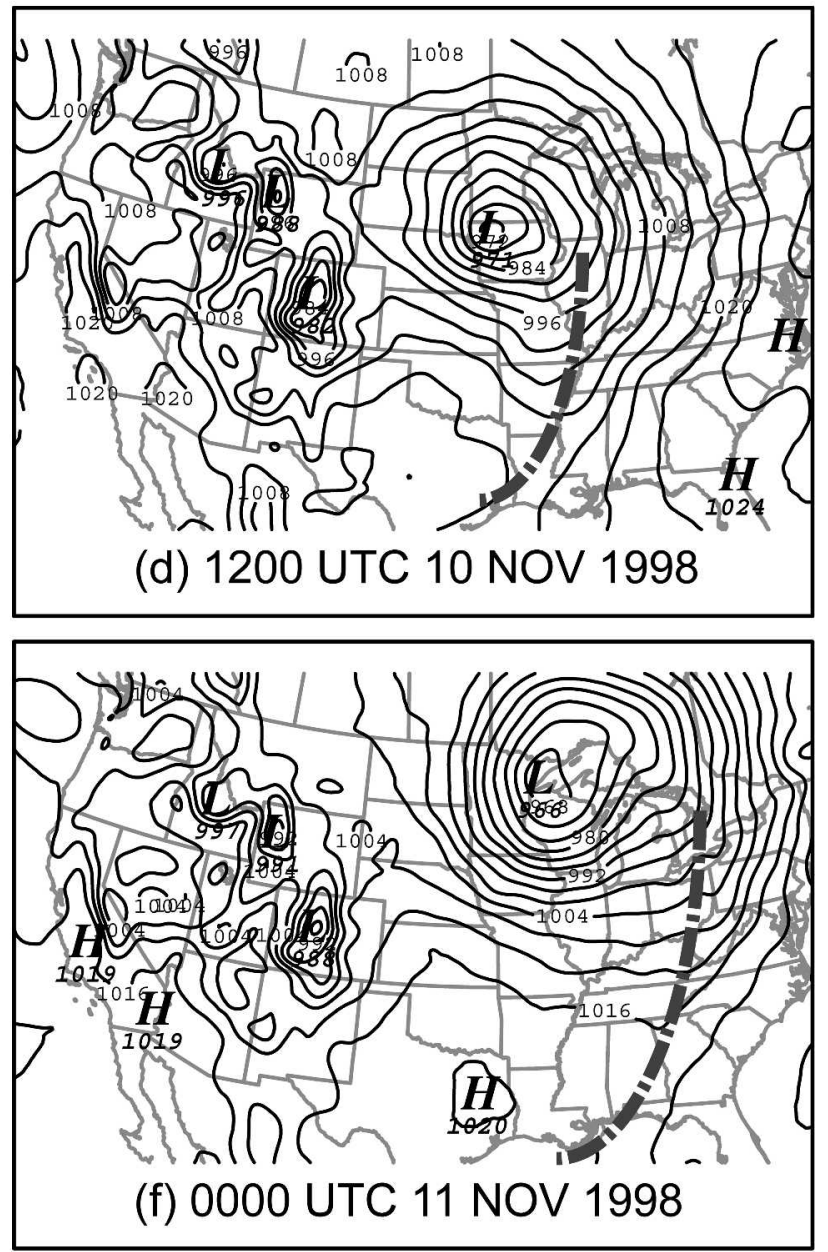

Sea Level Pressure

FIG. 1. RUC 500-mb geopotential height (solid lines every 6 dam) and absolute vorticity of total wind $\left[10^{-5} \mathrm{~s}^{-1}\right.$, shaded according to scale in (a)]: (a) 0000 UTC 10 Nov, (c) 1200 UTC 10 Nov, and (e) 0000 UTC 11 Nov 1998. Sea level pressure (solid lines every 4 $\mathrm{mb}$ ) and approximate location of convective line (gray dashed-dotted line): (b) 0000 UTC 10 Nov, (d) 1200 UTC 10 Nov, and (f) 0000 UTC 11 Nov 1998. 

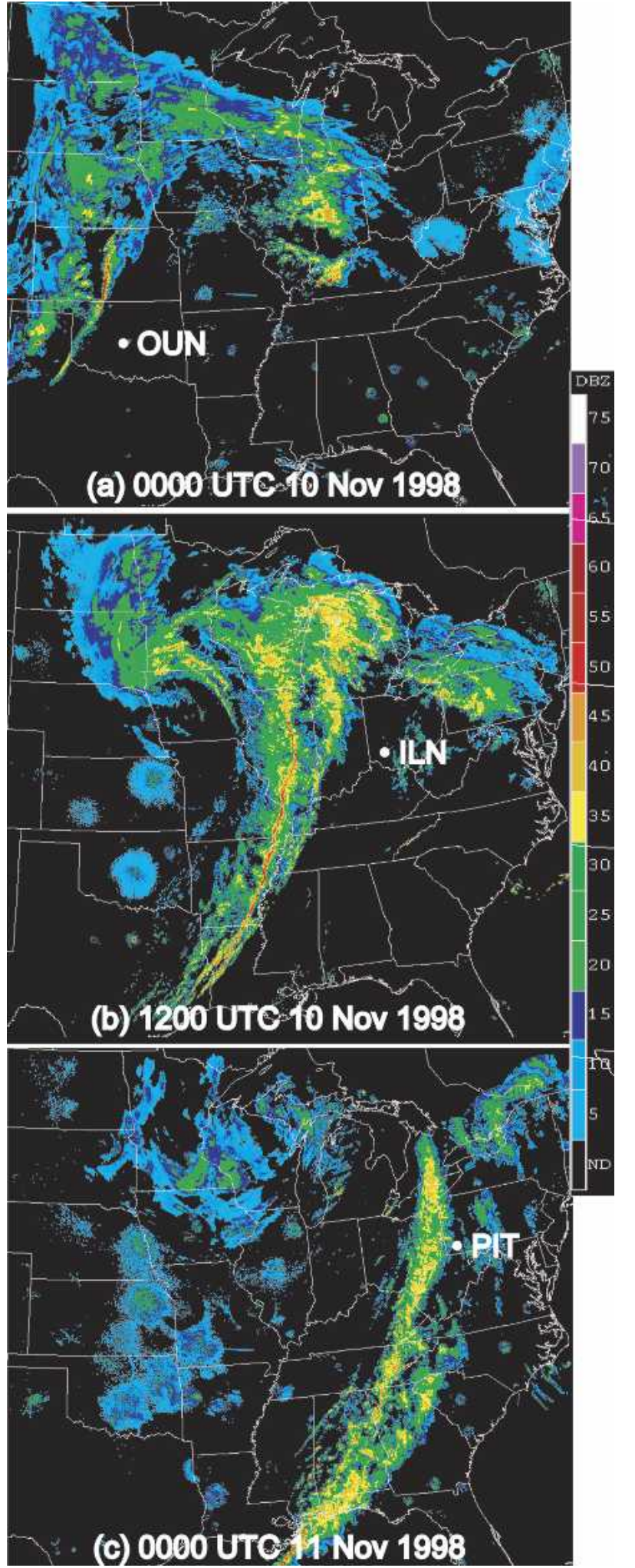

FIG. 2. National composite radar imagery: (a) 0000 UTC 10 Nov, (b) 1200 UTC 10 Nov, and (c) 0000 UTC 11 Nov 1998. Stations where soundings are displayed in Fig. 4 are labeled: OUN = Norman, OK; ILN = Wilmington, OH; and PIT = Pittsburgh, PA. tively tilted and closed off over Iowa (Fig. 1c), while the surface cyclone explosively deepened to $971 \mathrm{mb}$ (Fig. 1d). The convective line had lengthened, ranging from northern Illinois to nearly the Gulf of Mexico in Texas, and was associated with a narrow axis of radar reflectivity factor exceeding $50 \mathrm{dBZ}$ (Fig. 2b). Given the limited extent of the stratiform precipitation normal to the convective line, this line is best categorized as parallel stratiform (PS; Parker and Johnson 2000; Parker 2004). By 0000 UTC 11 November, the vertically stacked system slowly moved to the northeast over northern Wisconsin, and the surface cyclone deepened another $5 \mathrm{mb}$ (Figs. 1e,f), although the intensity and organization of the convective line waned (Fig. 2c).

Because this strong extratropical cyclone resembled a storm that sank the ship Edmund Fitzgerald on Lake Superior 23 yr earlier to the day, the cyclone has come to be known as the Edmund Fitzgerald II storm. The Edmund Fitzgerald II storm has been previously analyzed by Olsen et al. (2000), Iacopelli and Knox (2001), and Locatelli et al. (2002). Olsen et al. (2000) showed that the total ozone measured by the Total Ozone Mapping Spectrometer (TOMS) corresponded well to potential vorticity fields from a mesoscale analysis system. Iacopelli and Knox (2001) examined evidence for the association between a dry intrusion on satellite imagery, pilot reports of turbulence, and the nonconvective strong surface winds in Illinois, Iowa, Michigan, Minnesota, and Wisconsin (e.g., shaded area in Fig. 3). Whereas Locatelli et al. (2002) showed that the surface frontal structure and evolution of this extratropical cyclone were similar to those of the Norwegian cyclone model (e.g., Bjerknes and Solberg 1922), Olsen et al. (2000) stated that the upper-tropospheric evolution from this cyclone resembled the LC2 life cycle of Thorncroft et al. (1993).

Severe convective storm reports occurred along an extensive swath from north Texas to Pennsylvania, south of the dry intrusion and the nonconvective winds (Fig. 3). From 2200 UTC 9 November to 1200 UTC 11 November, 517 severe wind, 14 tornado, and 11 large hail reports were received (NOAA 1998). This event met the criteria for a derecho (Johns and Hirt 1987). Given such a strong surface low center, a strong cold front, a long-lived convective line, and $25-40 \mathrm{~m} \mathrm{~s}^{-1}$ wind speeds in the lowest $3 \mathrm{~km}$ (e.g., Figs. 4b,d,f), operational experience at the SPC suggests that extensive convective wind damage was very likely. The lack of continuous CG lightning throughout the event, however, was unexpected. Shortly after the convective line initiated, it produced frequent CG lightning in Kansas and Oklahoma, discussed in more detail in section 3a. 


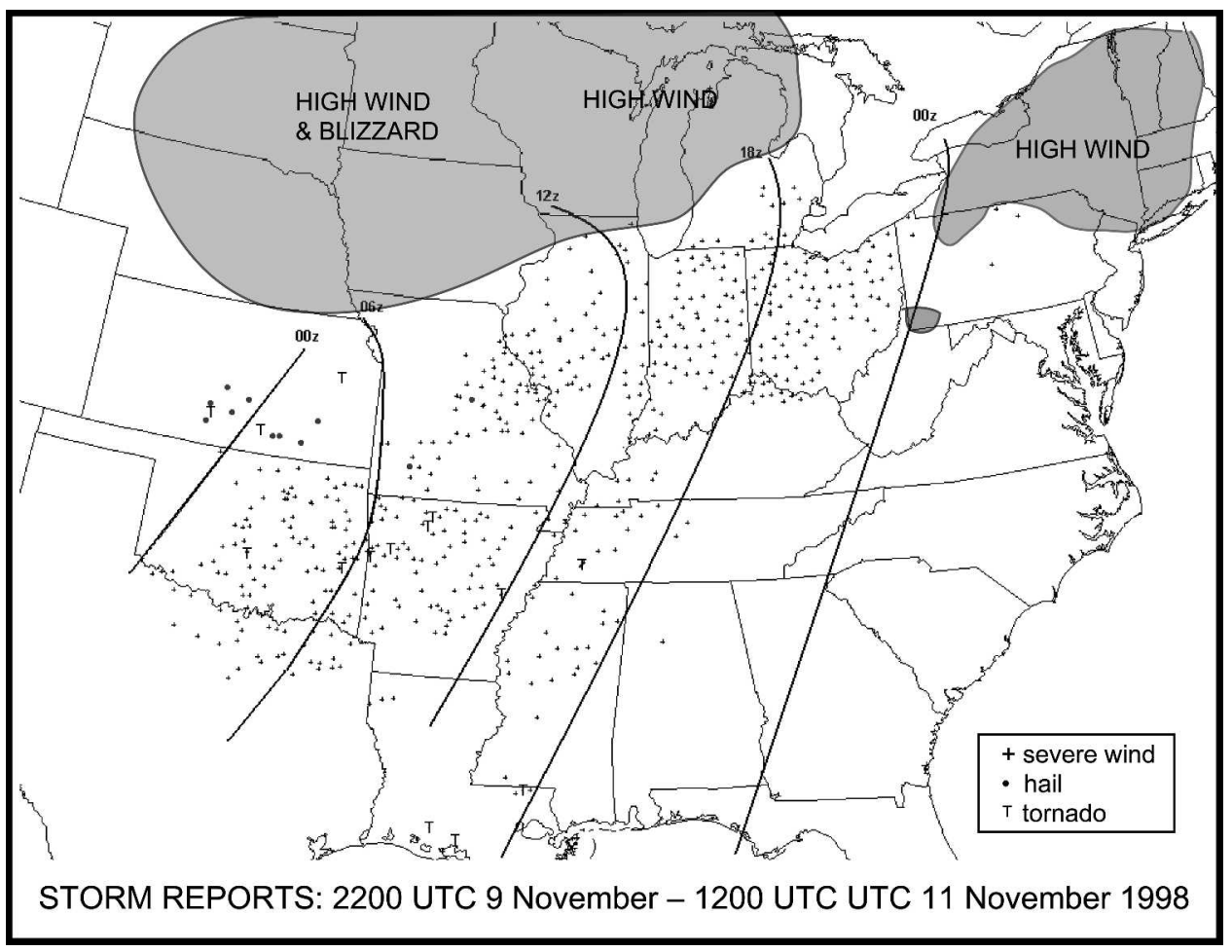

FIG. 3. Storm reports received by NOAA (1998). Solid lines represent approximate isochrones of report times; gray shading represents approximate regions of nonconvective high-wind or blizzard reports. Blizzard is defined as the following conditions lasting for $3 \mathrm{~h}$ or more: wind speeds greater than $35 \mathrm{mph}\left(15.6 \mathrm{~m} \mathrm{~s}^{-1}\right)$ and considerable falling and/or blowing snow with the visibility less than $0.25 \mathrm{mi}(0.4$ $\mathrm{km})$.

About $12 \mathrm{~h}$ after initiation, part of the line in Illinois and Indiana stopped producing CG lightning although the severe wind reports continued, discussed in section $3 \mathrm{~b}$. The line dissipated in Pennsylvania about $24 \mathrm{~h}$ after initiating (section 3c).

\section{a. Frequent CG lightning phase: 0000 UTC 10 November}

By 0000 UTC 10 November, about $4 \mathrm{~h}$ after its initiation, the convective line was producing CG lightning of over 50 flashes in a $40 \mathrm{~km} \times 40 \mathrm{~km}$ grid square in 3 h (Fig. 4a). [To verify its convective forecasts, the SPC constructs a $40 \mathrm{~km} \times 40 \mathrm{~km}$ gridded field every $3 \mathrm{~h}$ of the NLDN data. This gridded field is consistent with the grid spacing of the 40-km Rapid Update Cycle (RUC; Benjamin et al. 2004a,b) domain over the contiguous United States.] The 0000 UTC 10 November Norman, Oklahoma, sounding (Fig. 4b) showed a moderate amount of CAPE (1623 J kg$~^{-1}$ for the most unstable parcel). The mixed-phase region of the cloud $\left(-10^{\circ}\right.$ to $-40^{\circ} \mathrm{C}$ ) was located between approximately 550 and $300 \mathrm{mb}$, whereas the EL was $-64^{\circ} \mathrm{C}(189 \mathrm{mb})$. Cloudtop temperatures along the convective line measured from Geostationary Operational Environmental Satel- lite-8 (GOES-8) longwave infrared (channel 4) satellite imagery were typically $-60^{\circ}$ to $-70^{\circ} \mathrm{C}$ (not shown), indicating that parcels were reaching altitudes comparable to the sounding-derived EL. These observations indicate the presence of abundant instability and its release in a line of deep, moist convection. Given such instability, ascent of tens of meters per second was likely in the lower mixed-phase region of the cloud, the condition for charge generation. Thus, the conditions for CG lightning were present, as supported by the frequent CG lightning detected by the NLDN (Fig. 4a).

\section{b. Little CG lightning phase in Illinois and Indiana: 1200 UTC 10 November}

Although the radar imagery indicated an intense (reflectivity greater than $50 \mathrm{dBZ}$ ), narrow convective line at 1200 UTC 10 November (Fig. 2b), the CG lightning rates in the northern portion of the convective line over Illinois and Indiana decreased to near zero (Fig. 4c), marking a dramatic change in the evolution of the convective line. The 1200 UTC 10 November sounding from Wilmington, Ohio, best represented the preline environment (Fig. 4d), as the Lincoln, Illinois, sounding was missing. Interpreting the Wilmington sounding, 


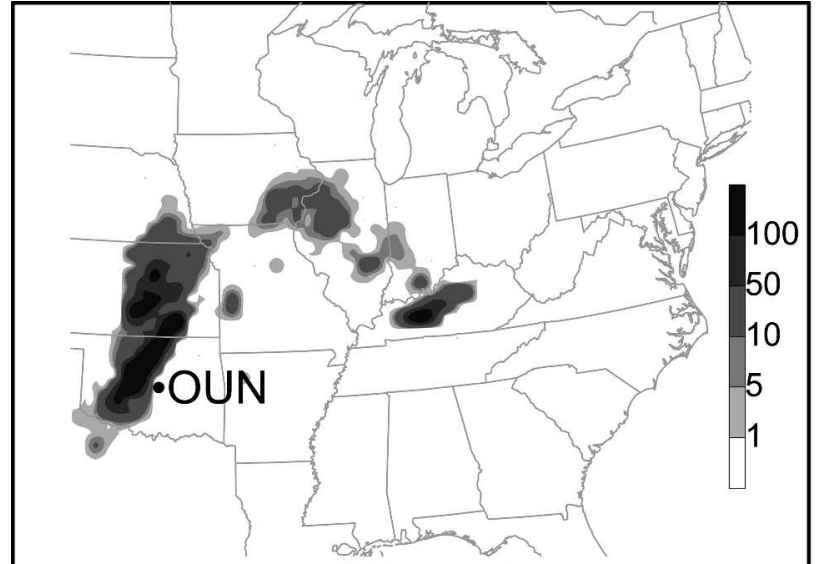

(a) 0000-0300 UTC 10 NOV 1998 LIGHTNING

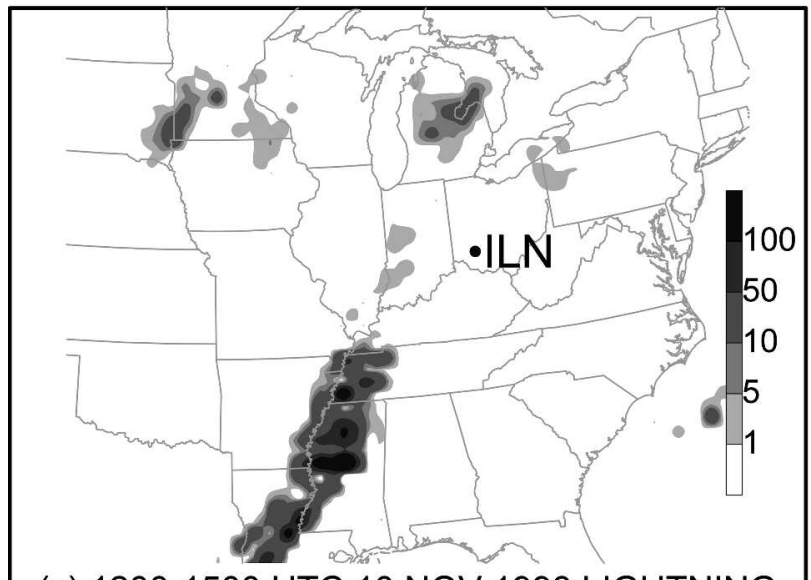

(c) 1200-1500 UTC 10 NOV 1998 LIGHTNING

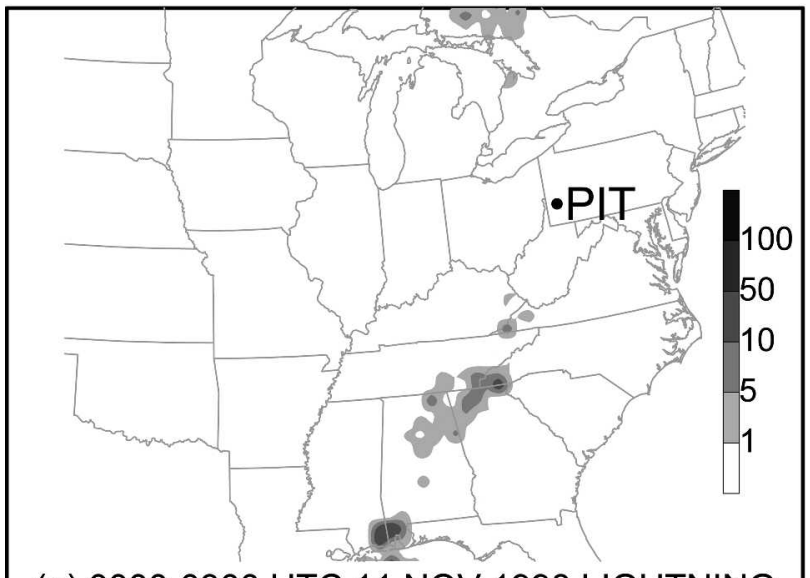

(e) 0000-0300 UTC 11 NOV 1998 LIGHTNING
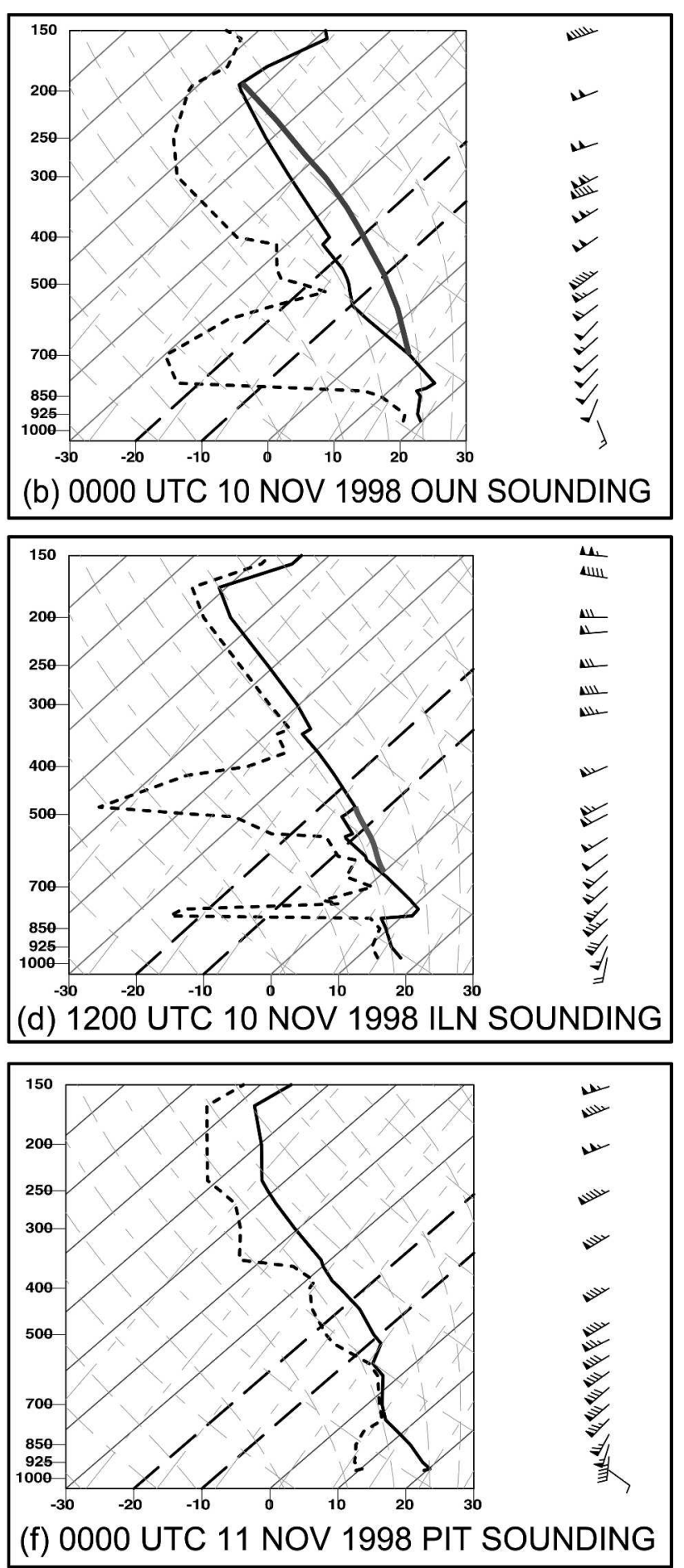

FIG. 4. Cloud-to-ground lightning detected by the NLDN (number of strikes per $40 \mathrm{~km} \times 40 \mathrm{~km}$ grid square per $3 \mathrm{~h}$ ): (a) $0000-0300$ UTC 10 Nov, (c) 1200-1500 UTC 10 Nov, and (e) 0000-0300 UTC 11 Nov 1998. Skew T-log $p$ of soundings identified in Figs. 2 and 4, highlighting the $-10^{\circ}$ and $-20^{\circ} \mathrm{C}$ isotherms (thick dashed diagonal lines), wind (one pennant, full barb, and half barb denote 25,5 , and $2.5 \mathrm{~m} \mathrm{~s}^{-1}$, respectively), and the path of the most-unstable parcel (thick solid gray line): (b) 0000 UTC 10 Nov at Norman, OK; (d) 1200 UTC 10 Nov at Wilmington, OH; and (f) 0000 UTC 11 Nov at Pittsburgh, PA. 
however, was problematic. Although this sounding had a most-unstable CAPE of $180 \mathrm{~J} \mathrm{~kg}^{-1}$ associated with a parcel lifted from about $700 \mathrm{mb}$, it is not clear that this thin layer of unstable air near $700 \mathrm{mb}$ was representative of the air releasing the instability in the actual storm. Regardless, nearly all the CAPE was located at temperatures higher than $-15^{\circ} \mathrm{C}$. On the other hand, a parcel lifted from the surface possessed zero CAPE, even after overcoming convective inhibition (CIN) near $800 \mathrm{mb}$ of $-318 \mathrm{~J} \mathrm{~kg}^{-1}$. Irrespective of the choice of parcel to lift, vigorous vertical motions within the lower mixed-phase region of the cloud were not likely to occur, ultimately limiting the potential for CG lightning, in agreement with the absence of flashes from the NLDN (Fig. 4c). Widespread damaging convective winds, however, continued to be reported during this phase (Fig. 3).

\section{c. Dissipation phase: 0000 UTC 11 November}

After 0000 UTC 11 November, the convective line had dissipated into a rainband extending from southeast Ontario to northern Georgia (Fig. 2c), and was producing few, if any, severe wind reports (Fig. 3) or CG lightning (Fig. 4e). The 0000 UTC 11 November sounding from Pittsburgh, Pennsylvania, was stable with zero CAPE (Fig. 4f). Thus, strong updrafts were unlikely in the lower mixed-phase region, limiting the potential for CG lightning production.

\section{The convective line of 9-10 March 2002}

The synoptic pattern for the 9-10 March 2002 event was similar to that of the 9-11 November 1998 convective line (cf. Figs. 1 and 5). At 0000 UTC 9 March, a short-wave trough was approaching the central United States (Fig. 5a), associated with a 994-mb surface low center over the Oklahoma-Kansas border (Fig. 5b). Two hours later, a line of previously isolated cells began to merge to form a convective line (Fig. 6a). This line lengthened so that by 0800 UTC 9 March, it ranged from isolated cells in northern Texas to an intense, and nearly continuous, convective line over Oklahoma, Missouri, and Iowa (Fig. 6b). This line produced large hail and severe convective wind reports in Kansas, but, by the time it was over Iowa, it was producing primarily severe wind reports (Fig. 7) and meeting the criteria for a derecho. This early phase of hail production transitioning to severe wind reports was similar to that of the 9-11 November 1998 event. By 1200 UTC 9 March, the short-wave trough moved eastward (Fig. 5c), and the circulation around the surface low intensified as it deepened $2 \mathrm{mb}$ and moved over Wisconsin (Fig. 5d). The convective line weakened by 1200 UTC (Fig. 6c), before reintensifying around 1800 UTC. The line began to narrow on radar by 2200 UTC, reaching its second peak intensity (Fig. 6d). At 0000 UTC 10 March, the $500-\mathrm{mb}$ trough intensified and became strongly negatively tilted (Fig. 5e), whereas the surface cyclone deepened $12 \mathrm{mb}$ and moved into southern Canada (Fig. 5f). The line intensified for a third time after 0000 UTC 10 March, moving through the mid-Atlantic states (Figs. 6e,f), and New England (not shown) through 1200 UTC 10 March.

In total, 306 severe convective wind and 82 hail reports were collected (NOAA 2002). These storm reports were found in two groups. The initial group of reports was found in a swath from Oklahoma to Wisconsin from 0100 through 0900 UTC 9 March (Fig. 7). Except for a patch of hail reports, mostly in Kansas, all the reports were severe convective wind reports. This first phase is discussed further in section 4a. High nonconvective winds (shaded areas in Fig. 7) were reported in Iowa, Minnesota, Wisconsin, and Michigan, associated with the deepening low center, and in Illinois and Indiana, associated with the cold front during its nonCG-lightning-producing phase, discussed in section $4 \mathrm{~b}$. A second band of convective wind reports occurred in Ohio, Pennsylvania, New York, and New Jersey from about 1900 UTC 9 March to 0700 UTC 10 March (Fig. 7) in association with its second phase of CG lightning production (section 4c). The patchwork of convective and nonconvective severe wind reports across Pennsylvania, New York, and New England in Fig. 7 illustrates the difficulty NWS personnel have in handling and classifying these events in a meteorologically consistent way (section 1). Though widespread wind damage occurred across much of central Pennsylvania, western New York, and New England (e.g., power was out, roofs were blown off buildings, and vehicles were overturned on interstates), some NWS forecast offices officially attributed the wind damage to nonconvective "high wind," whereas other offices classified the wind damage as "thunderstorm wind damage" (NOAA 2002).

\section{a. First CG lightning phase: 0000 UTC 9 March}

Shortly after convective initiation, the NLDN detected a high frequency of CG lightning ( $>50$ flashes per $40 \mathrm{~km} \times 40 \mathrm{~km}$ grid square per $3 \mathrm{~h}$ ) with the convective line (Fig. 8a). The 0000 UTC 9 March 2002 Topeka, Kansas, sounding, just east of initiation, showed most-unstable CAPE of $1010 \mathrm{~J} \mathrm{~kg}^{-1}$ (Fig. 8b). Cloud-top temperatures were $-50^{\circ}$ to $-60^{\circ} \mathrm{C}$ (not shown), consistent with the $\mathrm{EL}$ at $-52^{\circ} \mathrm{C}(262 \mathrm{mb})$. Abundant CAPE was located between the $-10^{\circ}$ and $-20^{\circ} \mathrm{C}$ isotherms, indicating the likelihood of strong 


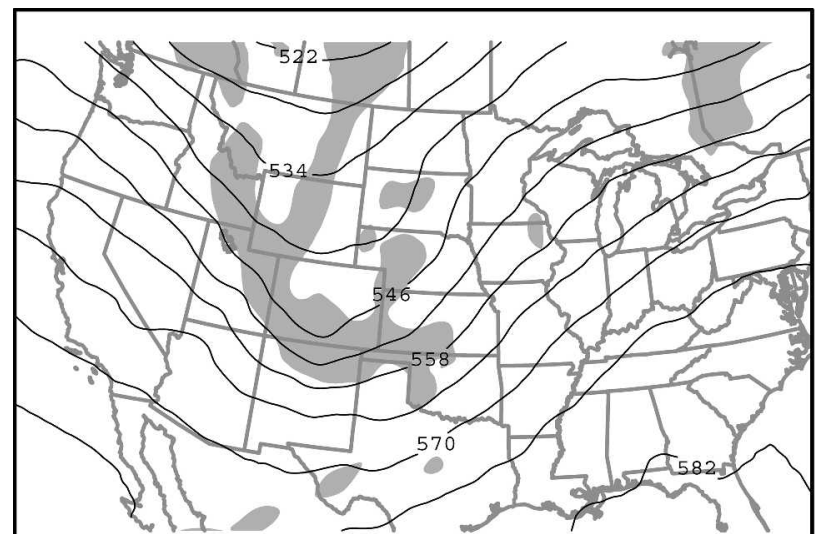

(a) 0000 UTC 9 MAR ${ }_{15} \mathrm{H}_{25} 2002$

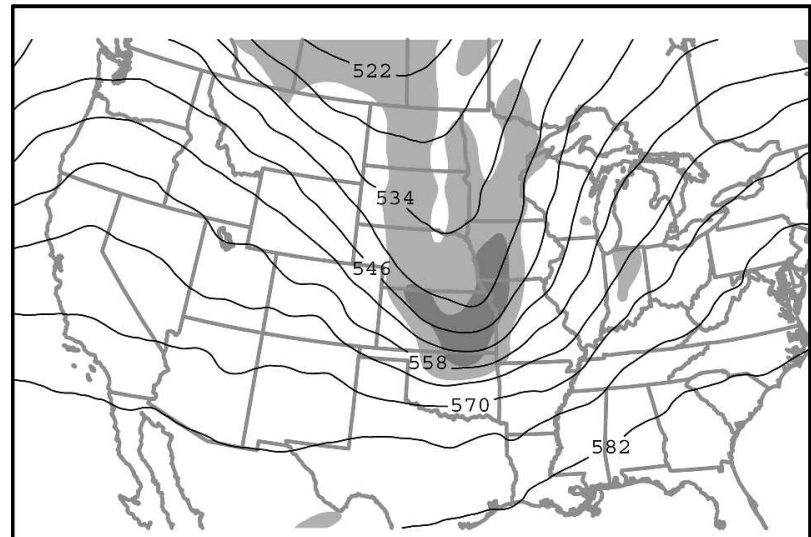

(c) 1200 UTC 9 MARCH 2002

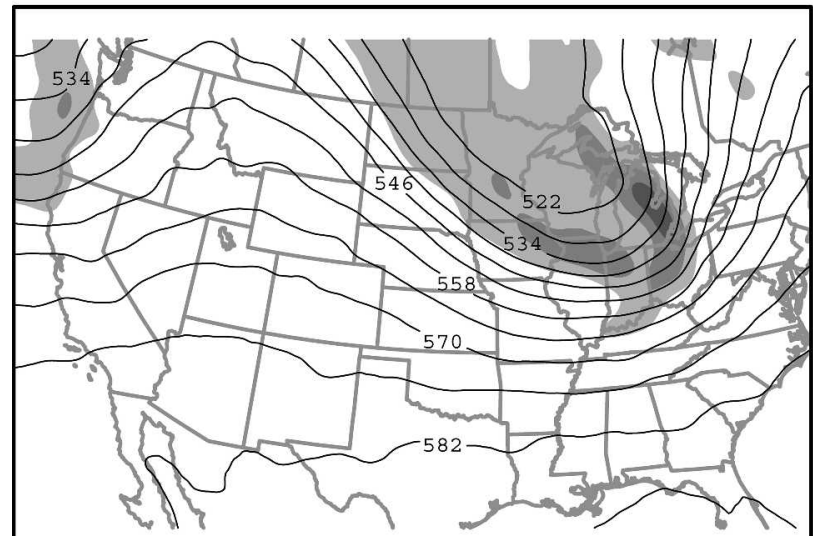

(e) 0000 UTC 10 MARCH 2002 500-mb Geopotential Height and Absolute Vorticity

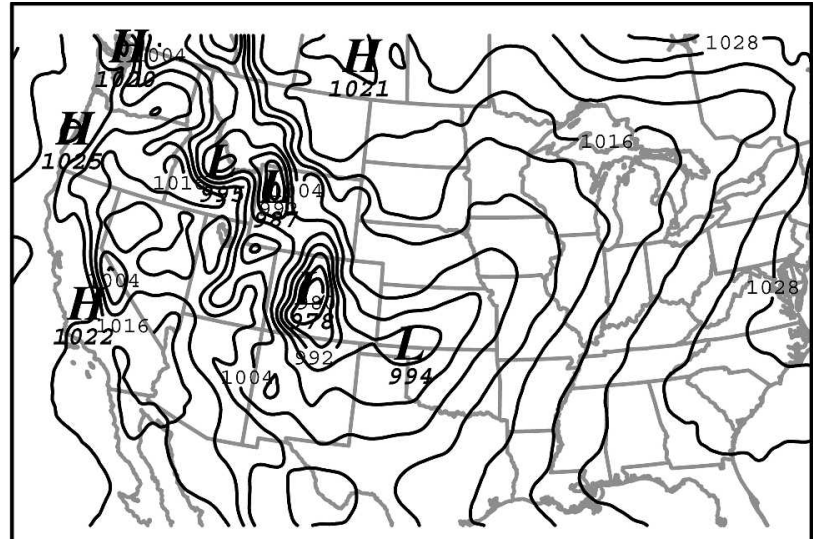

(b) 0000 UTC 9 MARCH 2002

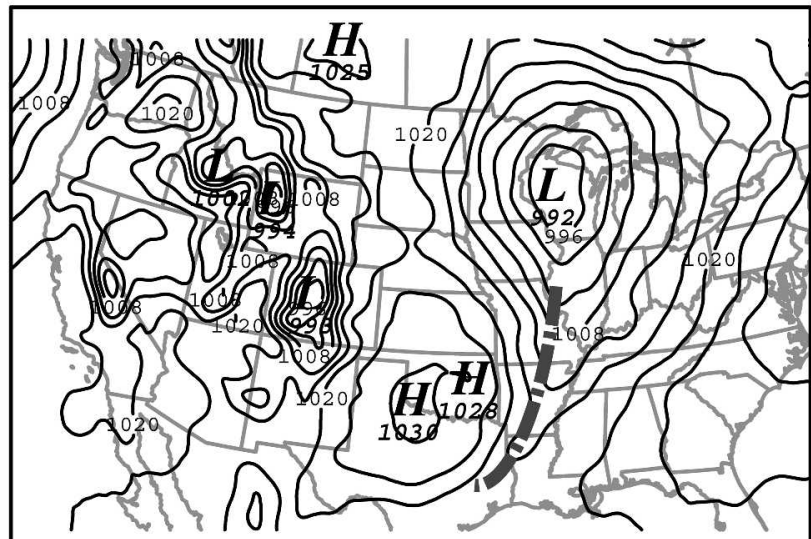

(d) 1200 UTC 9 MARCH 2002

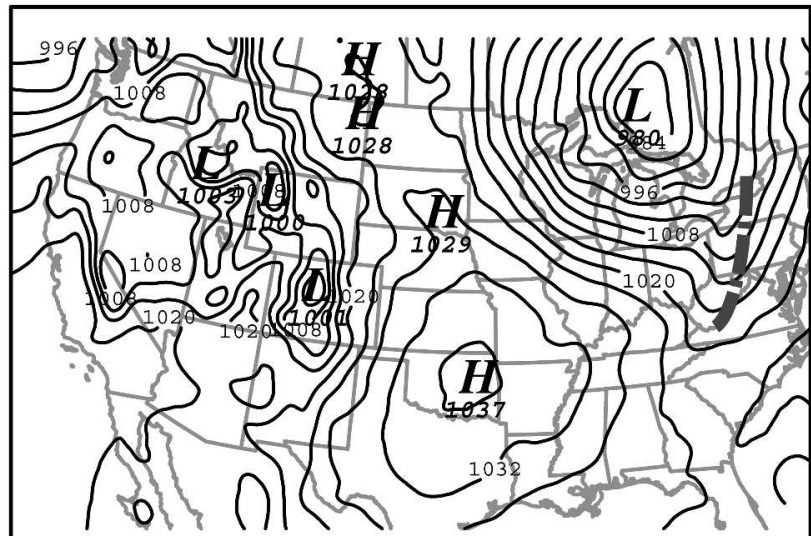

(f) 0000 UTC 10 MARCH 2002

\section{Sea Level Pressure}

FIG. 5. RUC 500-mb geopotential height (solid lines every 6 dam) and absolute vorticity of total wind $\left[10^{-5} \mathrm{~s}^{-1}\right.$, shaded according to scale in (a)]: (a) 0000 UTC 9 Mar, (c) 1200 UTC 9 Mar, and (e) 0000 UTC 10 Mar 2002. Sea level pressure (solid lines every 4 mb) and approximate location of convective line (gray dashed-dotted line): (b) 0000 UTC 9 Mar, (d) 1200 UTC 9 Mar, and (f) 0000 UTC 10 Mar 2002. 

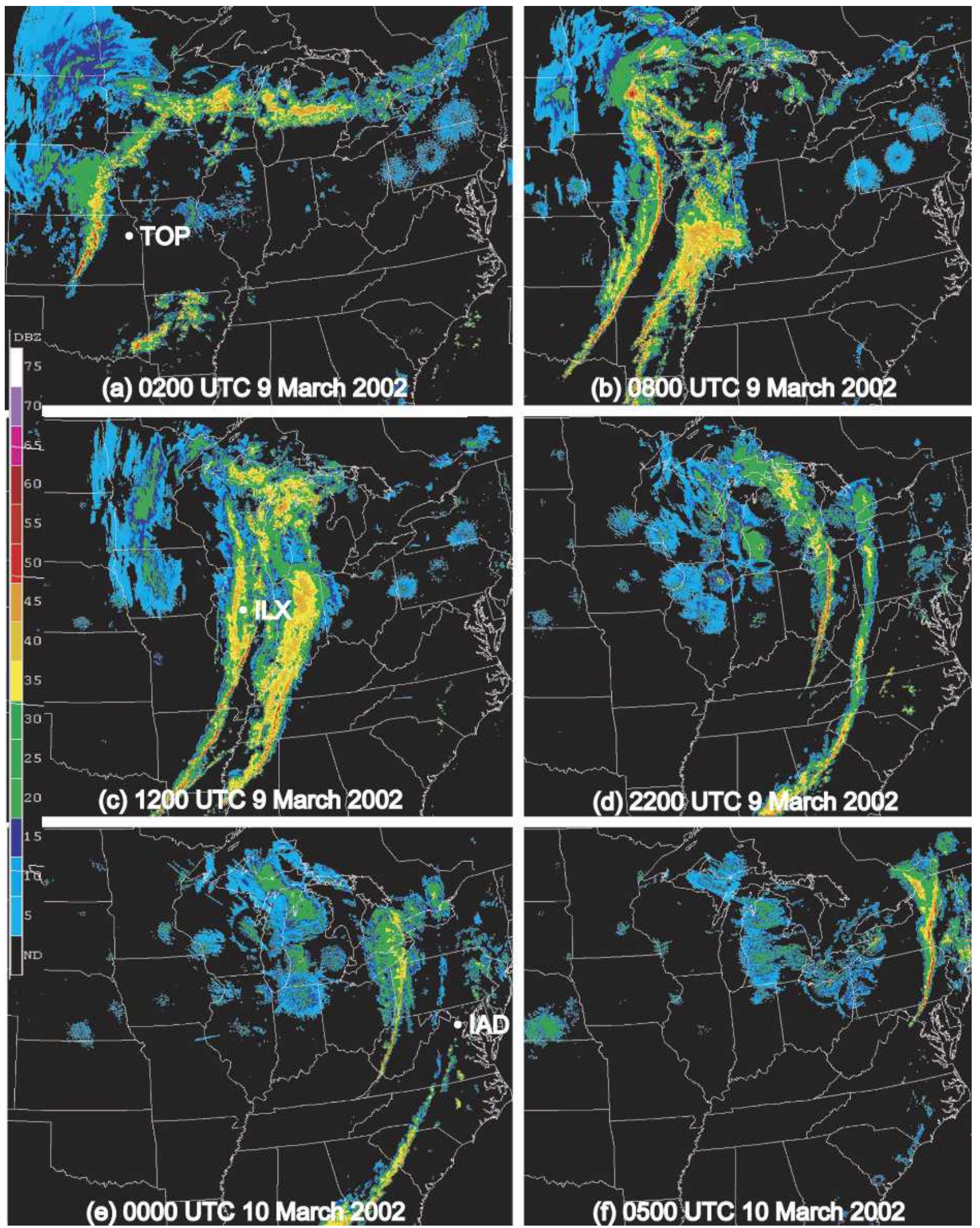

FIG. 6. National composite radar imagery: (a) 0200 UTC 9 Mar, (b) 0800 UTC 9 Mar, (c) 1200 UTC 9 Mar, (d) 2200 UTC 9 Mar, (e) 0000 UTC 10 Mar, and (f) 0500 UTC 10 Mar 2002. Stations where soundings are displayed in Fig. 8 are labeled: TOP = Topeka, KS; ILX = Lincoln, IL; and IAD = Sterling (Dulles Airport), VA. 


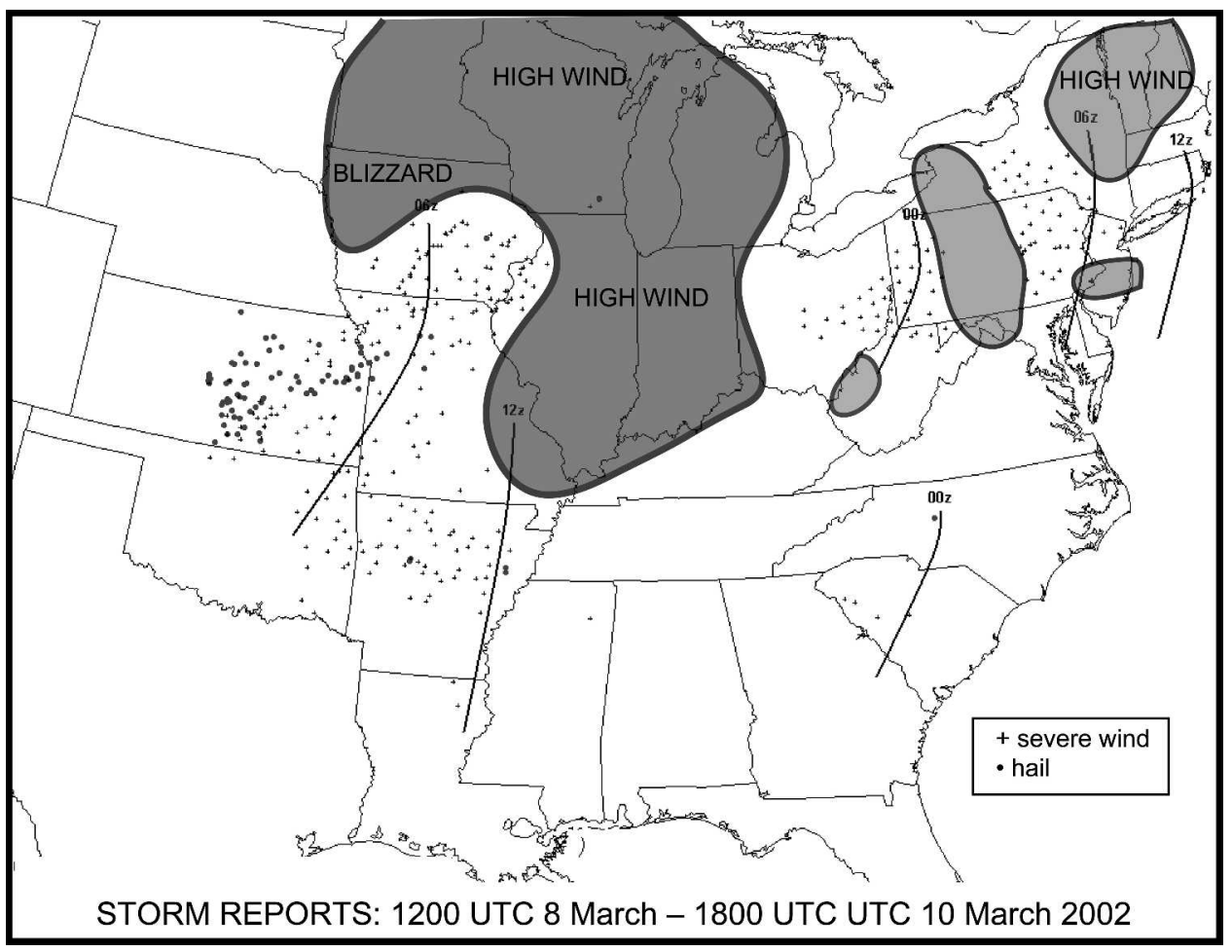

FIG. 7. Storm reports received by NOAA (2002). Solid lines represent approximate isochrones of report times; gray shading represents approximate regions of nonconvective high wind or blizzard reports.

convective updrafts in the lower mixed-phase region of the convection, favoring CG lightning (Fig. 8a).

\section{b. Little CG lightning phase: 1200 UTC 9 March}

The CG lightning along the northern portion of the convective line was no longer detected by the NLDN as the line moved into central Illinois around 1200 UTC (Fig. 8c). As with the no-lightning phase of the 9-11 November 1998 event (section 2b), soundings at 1200 UTC 9 March ahead of the convective line showed a substantial change in the environment had occurred (cf. Figs. 4d and 8d). The Lincoln, Illinois, sounding showed most-unstable CAPE of $60 \mathrm{~J} \mathrm{~kg}^{-1}$ (Fig. 8d) and an EL of $-11^{\circ} \mathrm{C}(562 \mathrm{mb})$. Given the near-moist-adiabatic profile of this sounding, this sounding was probably affected by the surrounding convection, thus neutralizing much of any instability that may have been present. Regardless, this near-moist-neutral air would be ingested into the convective line. All CAPE was located at temperatures warmer than $-10^{\circ} \mathrm{C}$ and no instability was present in the lower mixed-phase region of the convective line, thereby inhibiting the potential for CG lightning. Around 2200 UTC 9 March, the convection intensified into a narrow line with radar reflectivity ex- ceeding $50 \mathrm{dBZ}$ (Fig. 6d) and produced convective wind damage across central and eastern Ohio (Fig. 7), yet almost no CG lightning occurred (not shown).

\section{c. Second CG lightning phase: 0000 UTC 10 March}

After 0200 UTC 10 March, CG lightning again occurred along the convective line over central and eastern New York and Pennsylvania (Fig. 8e). Thermodynamic changes in the preline environment by 0000 UTC 10 March began to favor renewed CG lightning production. The obvious choice for a prefrontal sounding was from Albany, New York, but this sounding had no CAPE (not shown). Soundings at Albany from the RUC (not shown), however, indicated that the preline environment destabilized rapidly immediately before the passage of the convective line between 0300 and 0500 UTC, indicating CAPE in the lower mixed-phase region. The 0000 UTC 10 March Buffalo, New York, sounding (not shown) was just ahead of the convective line, but showed a moist absolutely unstable layer between about 700 and $800 \mathrm{mb}$, indicating that forced ascent saturated this layer faster than buoyant convection could remove the instability (e.g., Kain and Fritsch 1998; Bryan and Fritsch 2000). Such moist absolutely 


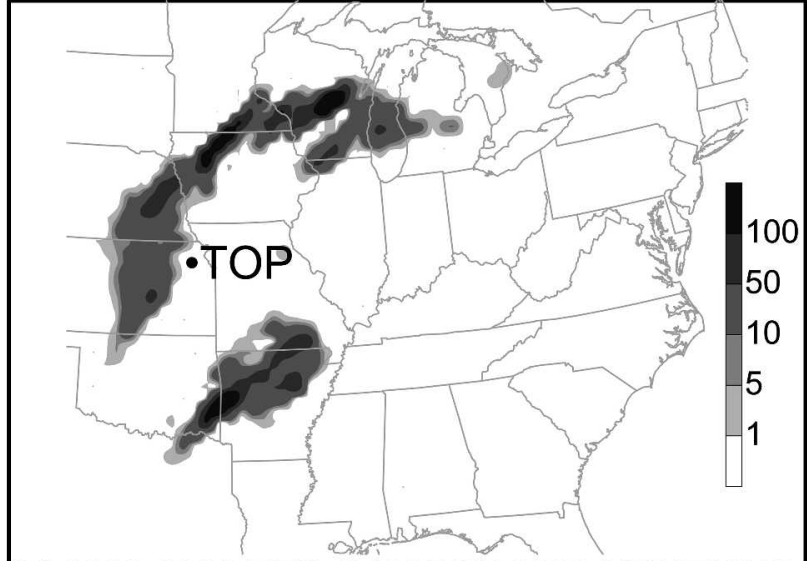

(a) 0000-0300 UTC 9 MARCH 2002 LIGHTNING

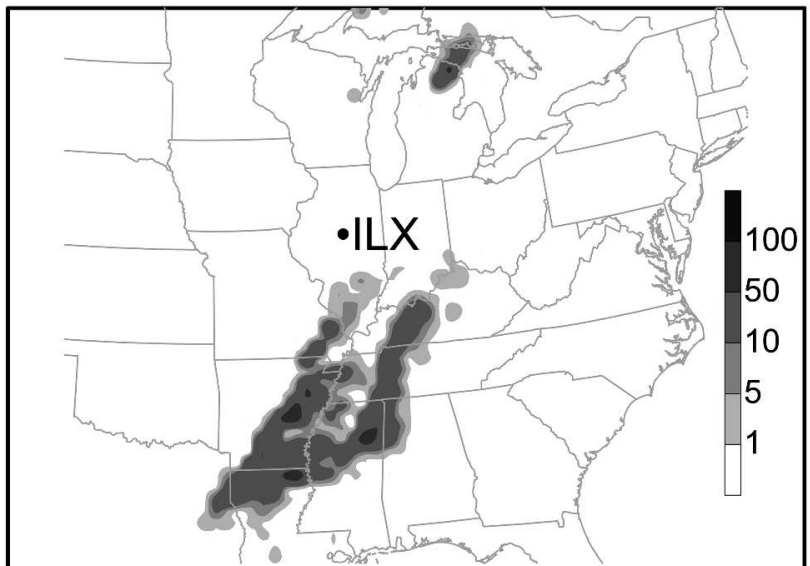

(c) 1200-1500 UTC 9 MARCH 2002 LIGHTNING

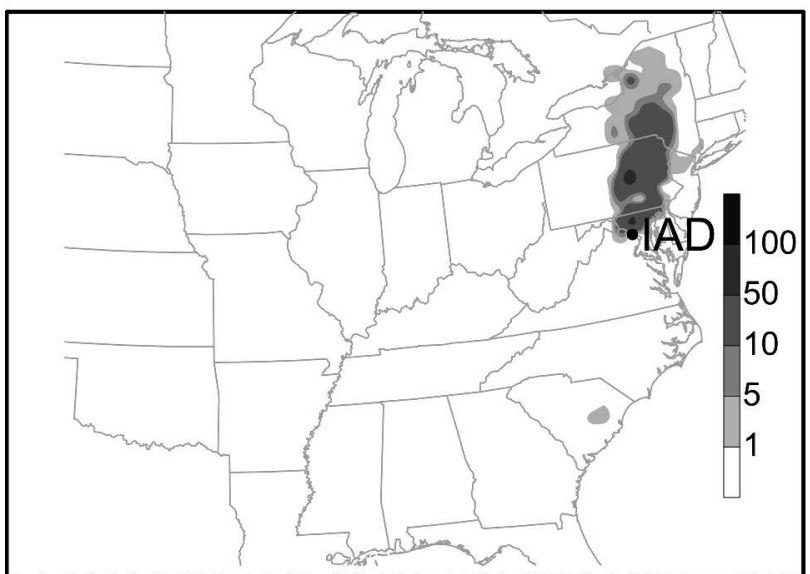

(e) 0300-0600 UTC 10 MARCH 2002 LIGHTNING

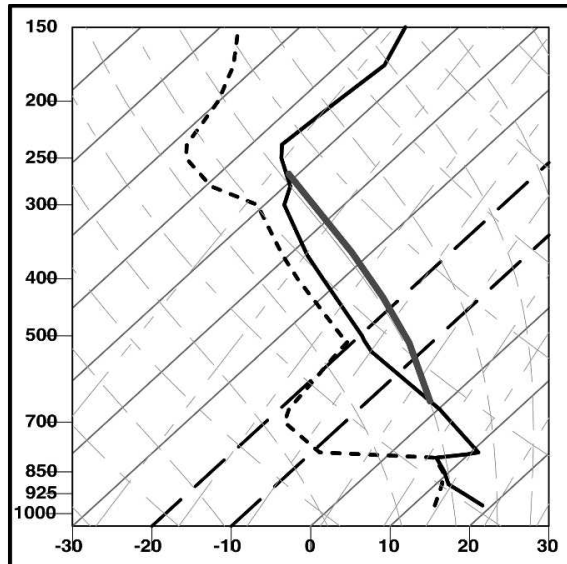

(b) 0000 UTC 9 MARCH 2002 TOP SOUNDING

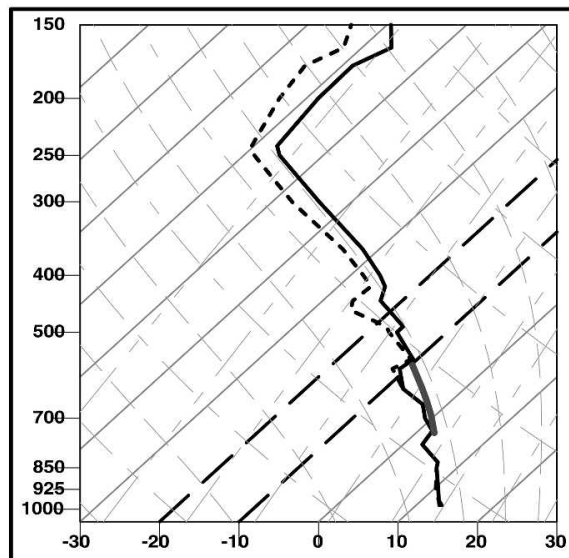

(d) 1200 UTC 9 MARCH 2002 ILX SOUNDING

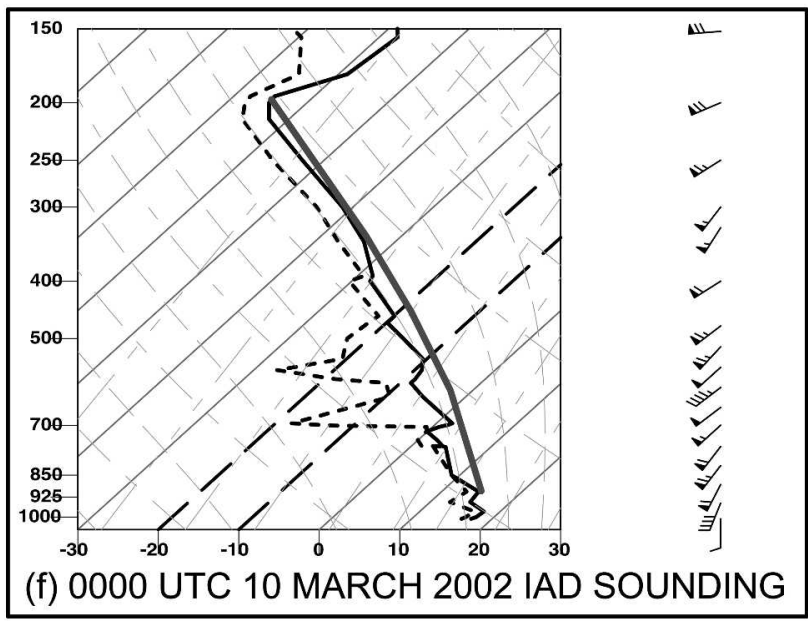

FIG. 8. Cloud-to-ground lightning detected by the NLDN (number of strikes per $40 \mathrm{~km} \times 40 \mathrm{~km}$ grid square per $3 \mathrm{~h}$ ): (a) $0000-0300$ UTC 9 Mar, (c) 1200-1500 UTC 9 Mar, and (e) 0300-0600 UTC 10 Mar 2002. Skew T-log $p$ of soundings identified in Figs. 6 and 8, highlighting the $-10^{\circ}$ and $-20^{\circ} \mathrm{C}$ isotherms (diagonal thick dashed lines), wind (one pennant, full barb, and half barb denote 25, 5, and $2.5 \mathrm{~m} \mathrm{~s}^{-1}$, respectively), and path of most-unstable parcel (thick solid gray line): (b) 0000 UTC 9 Mar at Topeka, KS; (d) 1200 UTC 9 Mar at Lincoln, IL; and (f) 0000 UTC 10 Mar at Sterling (Dulles Airport), VA. 
unstable layers are typically found within only a few to few tens of kilometers of the convective line (Bryan and Fritsch 2000). Thus, we considered the observed 0000 UTC Albany and Buffalo soundings unrepresentative of the pre-line environment. Instead, we selected the sounding from 0000 UTC Sterling, Virginia, to best represent the pre-line environment (Fig. 8f). Mostunstable CAPE of $1116 \mathrm{~J} \mathrm{~kg}^{-1}$ was present up to 200 $\mathrm{mb}$ and $-65^{\circ} \mathrm{C}$ (Fig. 8f), consistent with cloud-top temperatures as cold as $-60^{\circ} \mathrm{C}$ (not shown). There was abundant instability in the lower mixed-phase region of the cloud, indicating the potential for strong updrafts. After 0900 UTC, what little CG lightning remained was nearly all offshore (not shown), and convective wind damage on land ended (Fig. 7).

\section{Summary and SPC guidelines for these events}

Two strongly forced, low-instability convective lines (9-11 November 1998 and 9-10 March 2002) were examined to understand the factors controlling the production of CG lightning in these systems. Lightning is possible when there is sufficient CAPE to support vertical motions in excess of 6-7 $\mathrm{m} \mathrm{s}^{-1}$ within the lower mixed-phase region of the cloud (roughly $-10^{\circ}$ to $-20^{\circ} \mathrm{C}$ ), LCLs are warmer than $-10^{\circ} \mathrm{C}$, and ELs are colder than $-20^{\circ} \mathrm{C}$. These criteria were derived from earlier results from the lightning research community (as reviewed by MacGorman and Rust 1998, 218-220) and automated lightning prediction schemes (Bright et al. 2005). When little or no instability is found in the lower mixed-phase region, little to no CG lightning occurs along the convective line. Nevertheless, the convective line is still capable of producing severe weather, emphasizing that different ingredients are required for the development of damaging wind (e.g., Wakimoto 2001) versus CG lightning (e.g., MacGorman and Rust 1998, 218-220). As stated succinctly by Doswell (2001, p. 1), "hazardous weather can be produced by nonthundering convection."

Current SPC guidelines for forecasting these strongly forced, low-instability convective lines have been implemented by the NWS Eastern Region, where many of these lines occur. These guidelines are the following. Forecasters are to issue a severe thunderstorm watch for these strongly forced, low-instability convective lines in the following situations: 1) lightning is occurring within the line and damaging winds are expected, or 2) no lightning is occurring within the system, but a wellfocused line of convection is evident on the radar (i.e., $>50 \mathrm{~dB} Z$ echoes) and/or satellite imagery, and the damaging wind is primarily confined to the squall line. If synoptic-scale wind damage is expected in areas well removed from the convective line and the high-wind threat is expected to last for more than $1 \mathrm{~h}$, local forecast offices should issue high-wind warnings, although a severe thunderstorm watch may be prudent if the winds are expected to be substantially stronger with the convective line than in other areas.

Given the potential ambiguity that may arise in applying these guidelines to actual cases where both strong synoptic-scale and convective winds are expected, alternative approaches to handle these events more consistently may wish to be explored in the future.

Acknowledgments. The following people provided data, guidance, or comments that contributed to this paper: Phillip Bothwell, David Bright, Jeff Connors, Jason Levit, David Rust, Richard Thompson, Steve Weiss, Conrad Ziegler, and two anonymous reviewers. This material is based on work supported by the National Science Foundation to the National Weather Center Research Experiences for Undergraduates program under Grant 0097651. Funding for Schultz was provided by NOAA/OAR/NSSL under NOAA-OU Cooperative Agreement NA17RJ1227.

\section{REFERENCES}

Benjamin, S. G., G. A. Grell, J. M. Brown, T. G. Smirnova, and R. Bleck, 2004a: Mesoscale weather prediction with the RUC hybrid isentropic-terrain-following coordinate model. Mon. Wea. Rev., 132, 473-494.

—_, and Coauthors, 2004b: An hourly assimilation-forecast cycle: The RUC. Mon. Wea. Rev., 132, 495-518.

Bernardet, L. R., and W. R. Cotton, 1998: Multiscale evolution of a derecho-producing mesoscale convective system. Mon. Wea. Rev., 126, 2991-3015.

Bjerknes, J., and H. Solberg, 1922: Life cycle of cyclones and the polar front theory of atmospheric circulation. Geofys. Publ., 3 (1), 3-18.

Bright, D. R., M. S. Wandishin, R. E. Jewell, and S. J. Weiss, 2005: A physically based parameter for lightning prediction and its calibration in ensemble forecasts. Preprints, Conf. on Meteorological Applications of Lightning Data, San Diego, CA, Amer. Meteor. Soc., CD-ROM, 4.3.

Brooks, H. E., C. A. Doswell III, and J. Cooper, 1994: On the environments of tornadic and nontornadic mesocyclones. Wea. Forecasting, 9, 606-618.

Browning, K. A., 1990: Organization of clouds and precipitation in extratropical cyclones. Extratropical Cyclones, The Erik Palmén Memorial Volume, C. W. Newton and E. O. Holopainen, Eds., Amer. Meteor. Soc., 129-153.

_ ahead of mid-latitude cold fronts. Quart. J. Roy. Meteor. Soc., 99, 619-638.

Bryan, G. H., and J. M. Fritsch, 2000: Moist absolute instability: The sixth static stability state. Bull. Amer. Meteor. Soc., 81, 1207-1230.

Craven, J. P., R. E. Jewell, and H. E. Brooks, 2002: Comparison 
between observed convective cloud-base heights and lifting condensation level for two different lifted parcels. Wea. Forecasting, 17, 885-890.

Cummins, K. L., M. J. Murphy, E. A. Bardo, W. L. Hiscox, R. B. Pyle, and A. E. Pifer, 1998: A combined TOA/MDF technology upgrade of the U.S. National Lightning Detection Network. J. Geophys. Res., 103, 9035-9044.

Dorian, P. B., S. E. Koch, and W. C. Skillman, 1988: The relationship between satellite-inferred frontogenesis and squall line formation. Wea. Forecasting, 3, 319-342.

Doswell, C. A., III, 2001: Severe convective storms-An overview. Severe Convective Storms, Meteor. Monogr., No. 50, Amer. Meteor. Soc., 1-26.

— virtual temperature correction on CAPE calculations. Wea. Forecasting, 9, 625-629.

— and P. M. Markowski, 2004: Is buoyancy a relative quantity? Mon. Wea. Rev., 132, 853-863.

— H. E. Brooks, and M. P. Kay, 2005: Climatological estimates of daily local nontornadic severe thunderstorm probability for the United States. Wea. Forecasting, 20, 577-595.

Emanuel, K. A., 1994: Atmospheric Convection. Oxford University Press, $580 \mathrm{pp}$.

Evans, J. S., and C. A. Doswell III, 2001: Examination of derecho environments using proximity soundings. Wea. Forecasting, 16, 329-342.

Hinrichs, G., 1888: Tornadoes and derechos. Amer. Meteor. J., 5, 306-317, 341-349.

Holitza, F. J., and H. W. Kasemir, 1974: Accelerated decay of thunderstorm electric fields by chaff seeding. J. Geophys. Res., 79, 425-429.

Iacopelli, A. J., and J. A. Knox, 2001: Mesoscale dynamics of the record-breaking 10 November 1998 mid-latitude cyclone: A satellite-based case study. Natl. Wea. Dig., 25 (1), 33-42.

Johns, R. H., and W. D. Hirt, 1987: Derechos: Widespread convectively induced windstorms. Wea. Forecasting, 2, 32-49.

Kain, J. S., and J. M. Fritsch, 1998: Multiscale convective overturning in mesoscale convective systems: Reconciling observations, simulations, and theory. Mon. Wea. Rev., 126, 22542273.

Kasemir, H. W., F. J. Holitza, W. E. Cobb, and W. D. Rust, 1976: Lightning suppression by chaff seeding at the base of thunderstorms. J. Geophys. Res., 81, 1965-1970.

Koch, S. E., and P. J. Kocin, 1991: Frontal contraction processes leading to the formation of an intense narrow rainband. $M e$ teor. Atmos. Phys., 46, 123-154.

Locatelli, J. D., R. D. Schwartz, M. T. Stoelinga, and P. V. Hobbs, 2002: Norwegian-type and cold front aloft-type cyclones east of the Rocky Mountains. Wea. Forecasting, 17, 66-82.

Lucas, C., E. J. Zipser, and M. A. LeMone, 1994: Vertical velocity in oceanic convection off tropical Australia. J. Atmos. Sci., 51, 3183-3193.

MacGorman, D. R., and W. D. Rust, 1998: The Electrical Nature of Storms. Oxford University Press, 422 pp.
Maddox, R. A., K. W. Howard, and C. L. Dempsey, 1997: Intense convective storms with little or no lightning over central Arizona: A case of inadvertent weather modification. J. Appl. Meteor., 36, 302-314.

McCann, D. W., 1978: Severe convective storms with little or no thunder. Natl. Wea. Dig., 3 (2), 2-5.

Michimoto, K., 1991: A study of radar echoes and their relationship to lightning discharge of thunderclouds in the Hokuriku District. Part I: Observation and analysis of thunderclouds in summer and winter. J. Meteor. Soc. Japan, 69, 327-335.

_ 1993: A study of radar echoes and their relationship to lightning discharge of thunderclouds in the Hokuriku District. Part II: Observation and analysis of "single-flash" thunderclouds in midwinter. J. Meteor. Soc. Japan, 71, 195-204.

NOAA, 1998: Storm Data. Vol. 40, No. 11, 134 pp.

_, 2002: Storm Data. Vol. 44, No. 3, 189 pp.

Olsen, M. A., W. A. Gallus Jr., J. L. Stanford, and J. M. Brown, 2000: Fine-scale comparison of TOMS total ozone data with model analysis of an intense midwestern cyclone. J. Geophys. Res., 105, 20 487-20 495.

Parker, M. D., 2004: Simulated convective lines with parallel precipitation. Preprints, 22d Conf. on Severe Local Storms, Hyannis, MA, Amer. Meteor. Soc., CD-ROM, 6.3.

- and R. H. Johnson, 2000: Organizational modes of midlatitude mesoscale convective systems. Mon. Wea. Rev., 128, 3413-3436

Petersen, W. A., S. A. Rutledge, and R. E. Orville, 1996: Cloudto-ground lightning observations from TOGA COARE: Selected results and lightning location algorithms. Mon. Wea. Rev., 124, 602-620.

Reynolds, S. E., and M. Brook, 1956: Correlation of the initial electric field and the radar echo in thunderstorms. J. Meteor., 13, 376-380.

Rogers, R. R., and M. K. Yau, 1989: A Short Course in Cloud Physics. 3d ed. Pergamon, 293 pp.

Rust, W. D., and P. R. Krehbiel, 1977: Microwave radiometric detection of corona from chaff within thunderstorms. J. Geophys. Res., 82, 3945-3950.

Thorncroft, C. D., B. J. Hoskins, and M. E. McIntyre, 1993: Two paradigms of baroclinic-wave life-cycle behavior. Quart. J. Roy. Meteor. Soc., 119, 17-55.

Wakimoto, R. M., 2001: Convectively driven high wind events. Severe Convective Storms, Meteor. Monogr., No. 50, Amer. Meteor. Soc., 255-298.

Weiss, S. J., J. A. Hart, and P. R. Janish, 2002: An examination of severe thunderstorm wind report climatology: 1970-1999. Preprints, 21st Conf. on Severe Local Storms, San Antonio, TX, Amer. Meteor. Soc., CD-ROM, 11B.2.

Workman, E. J., and S. E. Reynolds, 1949: Electrical activity as related to thunderstorm cell growth. Bull. Amer. Meteor. Soc., 30, 142-144.

Zipser, E. J., 1994: Deep cumulonimbus clouds systems in the Tropics with and without lightning. Mon. Wea. Rev., 122, 1837-1851. 